\title{
Clonal propagation of galanga [Languas galanga (L.) Stuntz] through tissue culture ${ }^{1}$
}

\author{
Feiko H. Ferwerda ${ }^{2}$
}

\begin{abstract}
Buds of rhizomes from greenhouse grown galanga plants were excised and propagated clonally through tissue culture. The medium consisted of Murashige and Skoog (MS) salts, vitamins, $2 \%$ sucrose and $2 \mathrm{mg} / \mathrm{L}$ 6-benzylaminopurine (BA). Adventitious and axillary shoots were produced by repeated subculture at 4-week intervals. The rate of increase per explant was calculated conservatively to be four plants per plant per 4-week cycle.
\end{abstract}

\section{RESUMEN}

Propagación clonal de galanga, Languas galanga (L.) Stuntz, por cultivo de tejidos.

Se extrajeron y propagaron yemas de rizomas de plantas de galanga por cultivo de tejidos. Las yemas se sembraron en sales del medio de cultivo de Murashige y Skoog (MS), vitaminas, $2 \%$ de sacarosa y $2 \mathrm{mg} / \mathrm{L}$ de 6 -benzilaminopurina (BA). Se produjeron brotes axilares y adventicios al subcultivar las plantas cada 4 semanas. La razón de aumento por cada porción de tejido extraído y sembrado se calculó como una de aproximadamente cuatro plantas por cada ciclo de 4 semanas.

\section{INTRODUCTION}

Galanga is a spice obtained from the rhizome of Languas galanga (L.) Stunz, a member of the Zingiberaceae. It is widely used in Asia as a condiment in rice and meat dishes $(1,7)$. The increase of populations of Asian origin in the USA and Canada has increased the demand for spices derived from gingers such as ginger, turmeric and galanga (5). Galanga could become a specialty crop in Puerto Rico, supplying these markets with fresh rhizomes.

As in the case with ginger, galanga is propagated vegetatively through rhizome cuttings $(1,2,6,7)$. Growers save up to $30 \%$ of the rhizomes of their current crop and cut them into finger size pieces to be used a seeds. The disadvantage of this method of propagation is that rhizomes infected with pathogens automatically infect new plantings. Serious losses may occur because of Pseudomonas spp., Fusarium spp.

'Manuscript submitted to Editorial Board 6 June 1994.

${ }^{2}$ Research Assistant, Department of Horticulture. 
and root-knot nematodes such as Meloidogyne spp. (8). Producing seedlings through tissue culture will eliminate this source of pathogens. Planting pathogen-free seedlings may reduce disease incidence and increase yield. Reduction of rhizomes infected with pathogens may decrease post-harvest losses and increase storage time.

The purpose of this study was to use tissue culture to micropropagate galanga rapidly and to produce pathogen-free seedlings.

\section{MATERIALS AND METHODS}

Buds from greenhouse grown galanga rhizomes were excised and dissected until they were approximately $1 \mathrm{~cm}$ long. Then they were surface disinfected in a 10\% Clorox solution for 10 minutes and rinsed three times with sterile distilled water. They were then further dissected under sterile conditions approximately $5 \mathrm{~mm}$ and disinfected again in a $2 \%$ Clorox solution for 5 minutes and rinsed three times in sterile distilled water. Excised buds were cultured in a medium consisting of MS major and minor salts, MS vitamins and $2 \%$ sucrose (4). The media were supplemented with the growth regulators $B A$ and indoleacetic acid (IAA) at various concentrations. The $\mathrm{pH}$ was adjusted to 5.7 with $1 N$ potassium hydroxide. The cultures were grown in $25 \times 150$ $\mathrm{mm}$ borosilicate glass culture tubes at $28^{\circ} \mathrm{C}$ under $16 \mathrm{hr}$ of fluorescent cool white light at 3000 lux.

A factorial design was used with 10 cultures per treatment and combining five concentrations of BA $(0,1,2,4$ and $8 \mathrm{mg} / \mathrm{L})$ with five concentrations of $\operatorname{IAA}(0,1,2,4$ and $8 \mathrm{mg} / \mathrm{kg})$. The cultures were arranged in a complete randomized design. The plantlets were transferred to a fresh medium every 4 weeks. After four transfers, plantlets were multiplied for 32 weeks in a medium containing $2 \mathrm{mg} / \mathrm{kg}$ BA. To transfer plants to the greenhouse, micro-cuttings from tissue culture were treated for 5 minutes in Banrot fungicide solution (1/2 teaspoon per gallon) and planted in growing trays containing a 1 peat moss: 1-perlite potting medium. Hardening occurred under a mist system (6 seconds every 6 minutes) under $60 \%$ shade. After one week, plantlets were placed under $40 \%$ shade and watered twice a week with a Peters (WPS) $20-20-20$ solution ( $200 \mathrm{mg} / \mathrm{L}$ of nitrogen).

\section{RESULTS AND DISCUSSION}

In the initial 4 weeks of the experiments, $21 \%$ of the explants became contaminated and were discarded. Subsequent losses due to 
transfer to new media were less than $1 \%$. Shoots in the medium without growth regulators grew and produced roots, but only two plants produced an additional shoot. In a medium with $2 \mathrm{mg} / \mathrm{L}$. IAA and $1 \mathrm{mg} /$ $\mathrm{L} B A$ an average of 5.8 shoots were produced. An average of 2.8 of these shoots were adventitious. Shoots in this medium remained small $(1 \mathrm{~cm})$ and needed an additional 2 weeks after transfer to the greenhouse to develop roots. In a medium containing $2 \mathrm{mg} / \mathrm{L} \mathrm{BA}$ and $1 \mathrm{mg} / \mathrm{L} \mathrm{IAA}$, an average of 5.3 shoots were produced, among which an average of 1.2 were adventitious. These shoots rooted within a week under greenhouse conditions. In a medium with only $2 \mathrm{mg} / \mathrm{L} \mathrm{BA}$ an average of 4.2 axillary shoots were produced (Figure 1,2). Plants from this treatment rooted within a week. Two-month-old plants showed a normal development as compared to that of the mother plant (Figure 3).

Because of the nature of shoot proliferation, this last medium was chosen for subsequent propagation.

Axillary shoot formation tends to be genetically more stable; therefore, it is the preferred method for commercial propagation (3). Losses

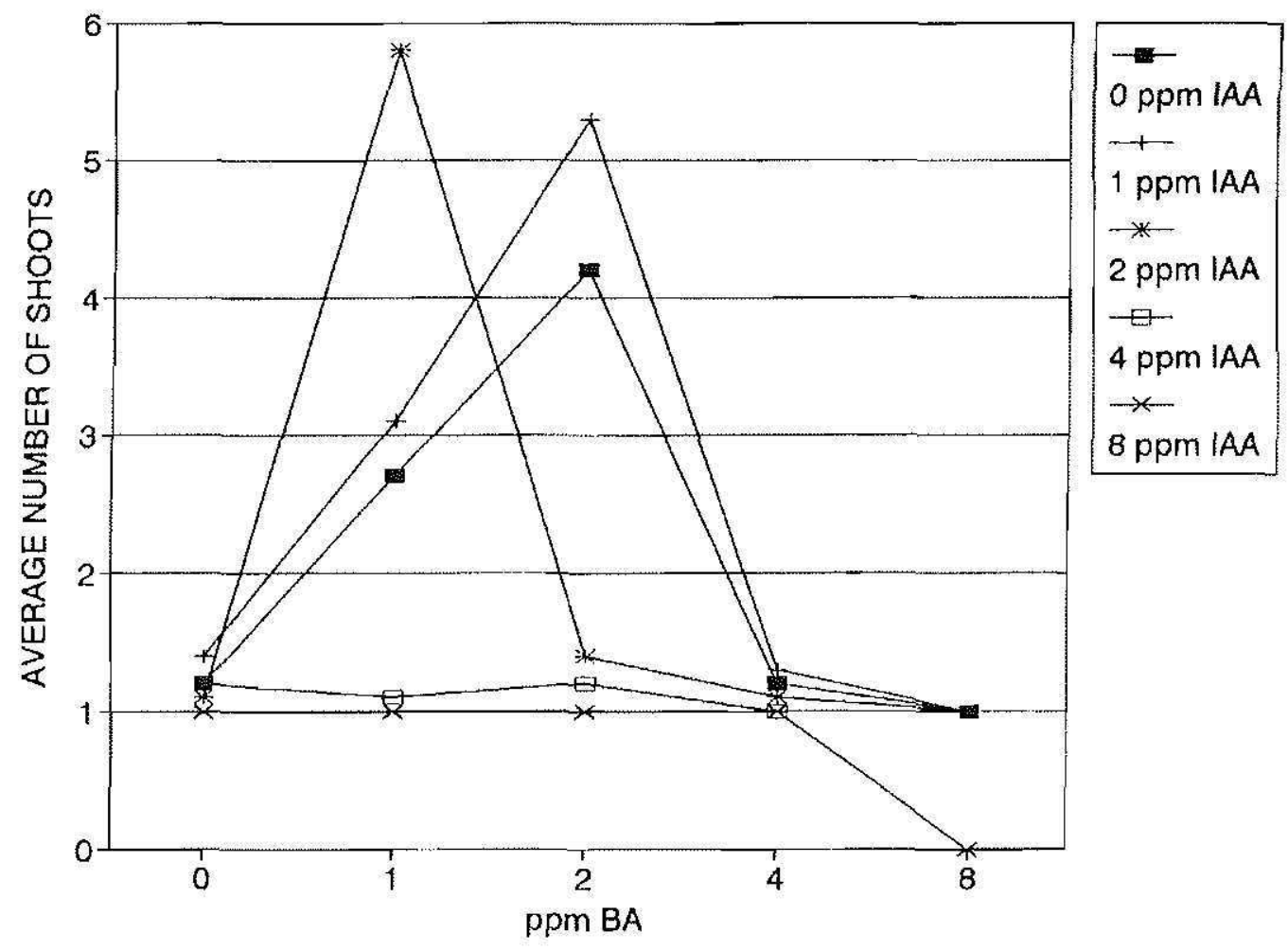

FIG. 1. Effect of IAA and BA concentrations on the number of shoots of galanga plants produced through tissue culture. 


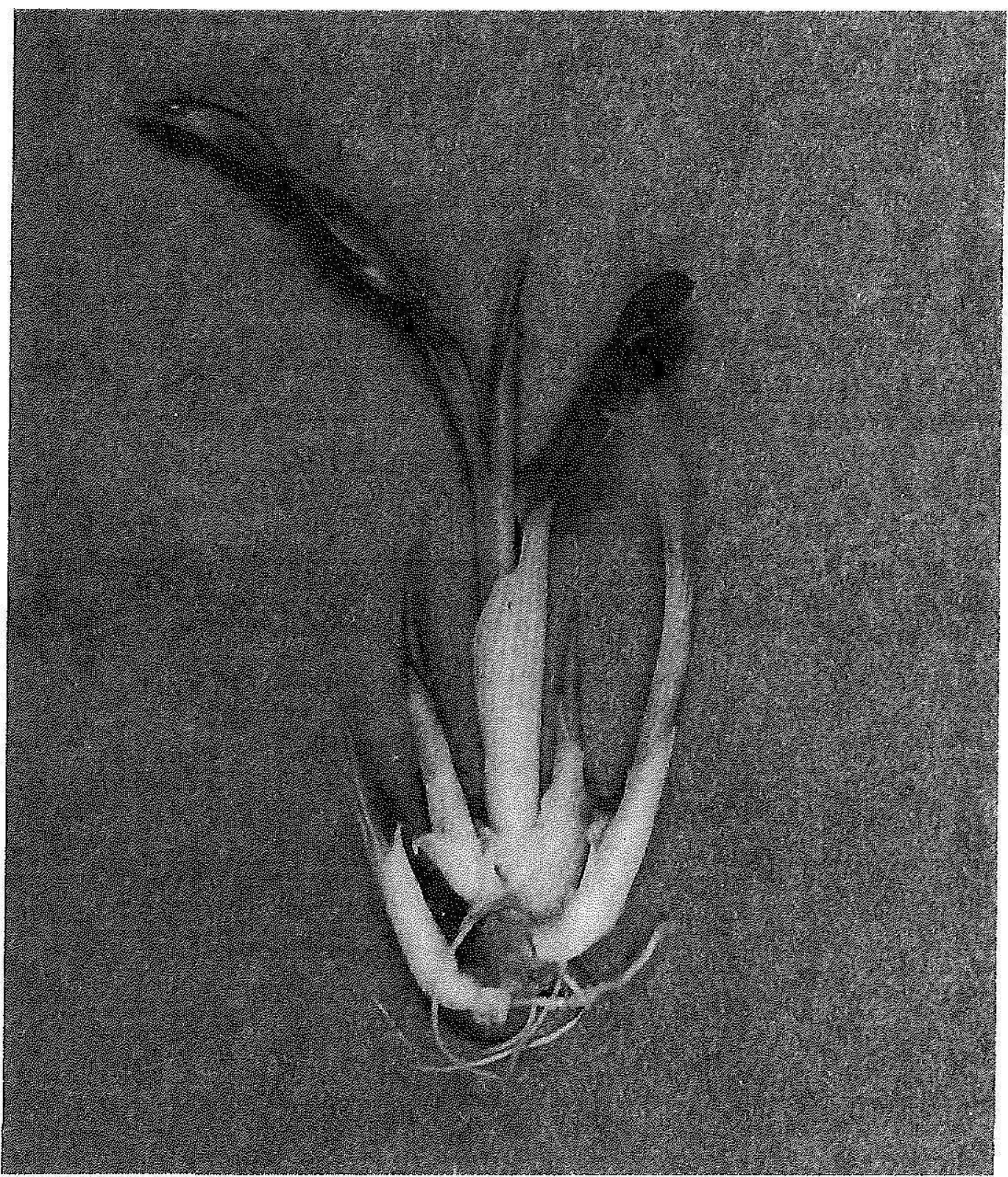

F]G. 2. Galanga plantlet out of culture showing lateral multiple axillary shoot formation and some roots.

due to transfer from tissue culture to the greenhouse totaled $2.4 \%$ at 4 weeks after transfer.

This study indicated that using tissue culture to propagate galanga offers the benefit of producing pathogen-free plantlets in predictable numbers of a homogenous quality. 


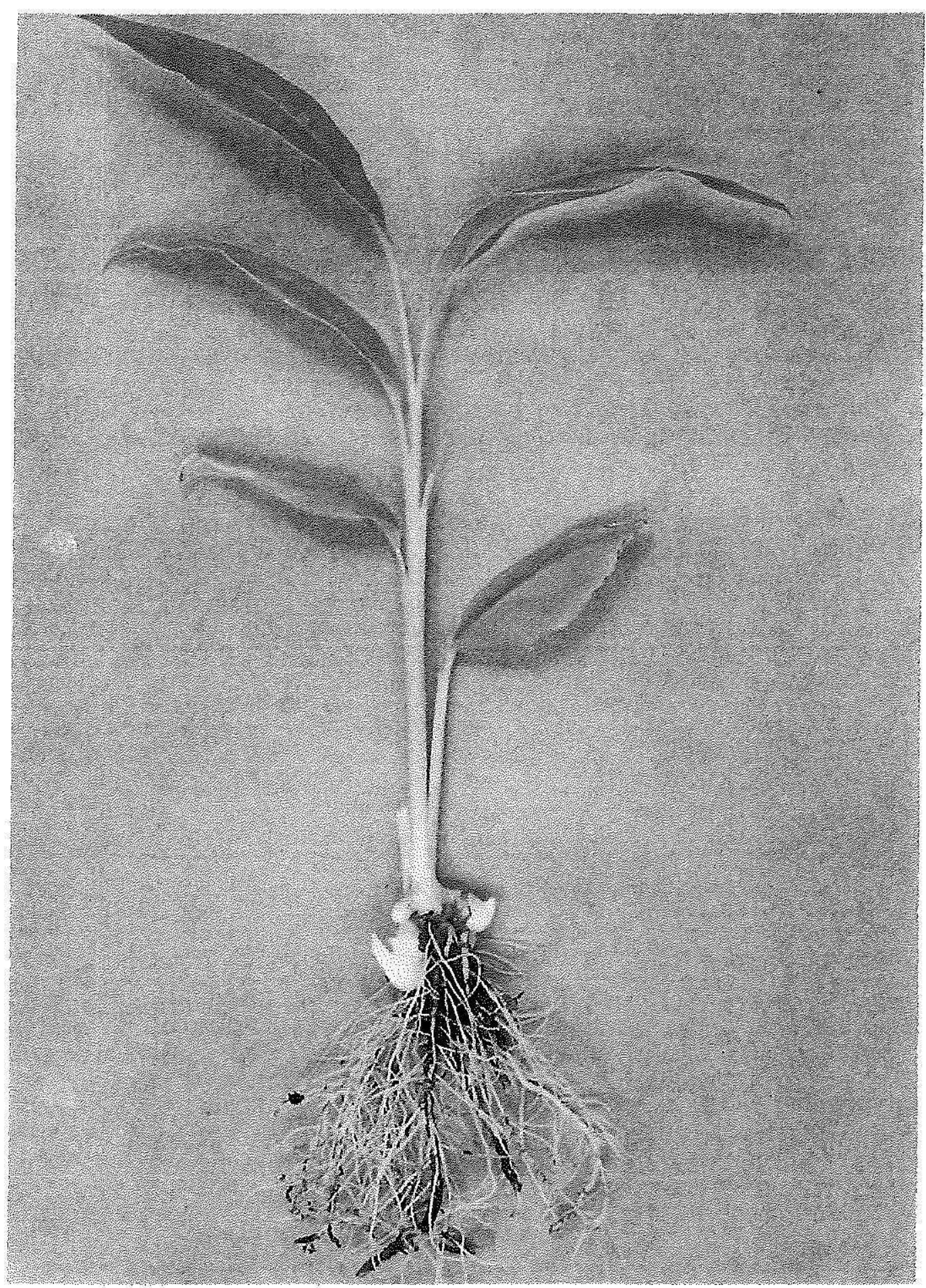

FIG. 3. Two-month-old galanga plant showing complete development of shoots, strong roots and emerging thizomes and buds. 


\section{LITERATURE CITE}

1. Hoskoi, T. and Sagawa, Y., 1977. Clonal propagation of ginger (Zingiber officinale Roscoe) through tissue culture. Hort Science 12 (5).

2. Ikeda, L.R. and M.J. Tanabe, 1989. In vitro subculture applications for ginger. HortScience 24(1).

3. Lindsey, K. and M.G.K. Jones, 1990. Plant biotechmology in agriculture. Prentice Hall, New Jersey.

4. Murashige, T., and F. Skoog, F., 1962. A revised medium for rapid growth and bioassays with tobacco tissue cultures. Physiol. Plant. 15: 473-97.

5. Nadgauda, R.S. and A.F. Mascrenhas, 1986. A method of screening high curcumin containing turmeric, Curcuma longa (L.), cultivars in vitro. J. Plant Physiol. 124(3/4).

6. Pillai, S.K. and K.B. Kumar, 1982. Note on the clonal multiplication of ginger in vitro. Indian J. Agric Sci. 52(6).

7. Purseglove, G, 1974. Thopical crops. Longmans, London.

8. Trujillo, E.E., 1964. Diseases of Ginger (Zingiber officinale Roscoe) in Hawaii. Agric. Expt. Sta. Cir. 62. 